\title{
A RECUPERAÇÃO DE DANOS ECOLÓGICOS NO DIREITO BRASILEIRO
}

\author{
Paulo de Bessa Antunes \\ Doutor em Direito pela Universidade do Estado do Rio de Janeiro (UERJ). \\ Mestr e em Direito pela Pontifícia Universidade Católica do Rio de Janeiro (PUC-Rio). \\ Professor da Universidade Federal do Estado do Rio de Janeiro (UNIRIO). \\ Procurador Regional da República. \\ Email: paulo.bessa.antunes@gmail.com
}

\begin{abstract}
RESUMO
Este artigo analisa a questão da recuperação de danos ecológicos no Direito Brasileiro do ponto de vista crítico, ao trazer as nuances e diferenças entre os danos ecológicos e os danos ambientais, além de discutir como a questão da recuperação dos danos é abordada no direito comparado. A metodologia adotada se baseou em diferentes revisões como a da literatura, da legislação nacional e estrangeira e a revisão da análise de precedentes judiciais acerca do tema. Os objetivos principais do presente trabalho são a desmistificação e a avaliação crítica da visão romântica relacionada à recuperação natural, entendida como o retorno do meio ambiente ao status quo ante ao dano. Constatou-se que a referida recuperação deve, em verdade, buscar uma aproximação ao status do meio ambiente anteriormente ao dano, mas não a sua recuperação completa ou pura, já que isso se configuraria como um objetivo impossível, sobretudo pela inexistência de bancos de dados confiáveis e atualizados sobre os aspectos de qualidade ambiental que possam ser utilizados como parâmetro de comparação entre os aspectos do ambiente antes do dano e após o dano. Conclui-se que a indenização pecuniária é uma obrigação secundária, sendo devida apenas quando não for possível recuperar os danos ecológicos.
\end{abstract}

Palavras-chave: Recuperação de danos ecológicos; Dano Ecológico; Dano Ambiental. 
THE ECOLOGICAL DAMAGES RECOVERY UNDER

THE BRAZILIAN LAW

\begin{abstract}
This paper analyzes the ecological damages recovery under the Brazilian Law from a critical point of view, by studying the peculiarities and differences between ecological damages and environmental damages, as well as discussing how the aspect of recovery of damages is addressed in the comparative law. The methodology was based on a review of the national and foreign literature and legislation, as well as an analysis of court precedents on this matter. The main objectives of the present paper are the demystification and the critical assessment of the romantic vision related to the natural recovery, understood as the return of the environment to the status quo before the damage had occurred. It was verified that this recovery must, as a matter of fact, seek an approximation to the status of the environment prior to the damage, but not its complete or pure recovery, since this scenario would be an impossible object, mainly due to the lack of reliable and updated databases on the aspects of environmental quality that can be used as a parameter of comparison between the environment before the damage and the environment after the damage. It was concluded that the pecuniary indemnification is a secondary obligation, that is only can be imposed when it is not possible to recover the ecological damages.
\end{abstract}

Keywords: Recovery of environmental damages; Ecological Damage; Environmental Damage. 
"Não é possivel retornar a um estado harmonioso com a natureza, no sentido em que voltar para trás implicaria uma regressão total, isto é, o retorno à vida animal"

Karl Popper

\section{INTRODUÇÃO}

Este artigo tem por objetivo realizar um exame sobre a recuperação dos danos ao meio ambiente, que é um dos temas mais relevantes do Direito Ambiental, muito embora não tenha merecido da doutrina a devida atenção. De fato, a maior parte da literatura disponível se dedica ao estudo do sistema de responsabilidade ambiental, seja ela administrativa, civil ou penal, pouco se aprofundando na seara da reparação das lesões ambientais, havendo uma forte tendência à confusão de reparação dos danos com a indenização pecuniária. Da mesma forma, percebe-se uma tendência doutrinária e jurisprudencial, que enfrenta a questão, à introdução do conceito de dano moral coletivo, o qual, indiscutivelmente, é um reconhecimento tácito da incapacidade de lidar com a crucial problemática da reparação dos danos ambientais, sendo poucas as obras que lhes são destinadas.

O meio ambiente lesado em decorrência de atividades antrópicas deve ser recuperado por aquele que tenha dado causa à lesão, como decorre da simples aplicação do princípio da responsabilidade (ANTUNES, 2016, p. 55). Todavia, a reparação dos danos ao meio ambiente é, ordinariamente, mais complexa do que a reparação de danos causados a outros tipos de bens. Em primeiro lugar, há que se observar que boa parte dos bens ambientais são bens infungíveis, ou seja, não podem ser substituídos por outros de igual condição. Tome-se o exemplo da extinção de uma espécie ou da destruição de uma paisagem notável, bens fora do comércio e, portanto, de difícil monetarização. Registre-se que muitos bens ambientais estão classificados como fora de comércio e, ao mesmo tempo, mantêm forte vínculo afetivo com a comunidade. Assim, em muitos casos, diante das dificuldades econômicas, há uma inclinação da doutrina e mesmo da jurisprudência para estabelecer uma indenização pecuniária para os danos causados ao meio ambiente. Este artigo, todavia, demonstrará que a solução não é compatível com a natureza específica dos danos ambientais. Para tal, será necessário que se estabeleça uma demarcação clara do que se 
entende por dano ambiental e de quais são as suas modalidades perante o direito brasileiro.

Metodologicamente, o artigo estabelecerá a necessária distinção entre (i) danos ambientais e (ii) danos ecológicos. Essa questão preliminar é fundamental, pois o direito brasileiro utiliza o conceito amplo de dano ambiental, nele compreendidos os danos às atividades econômicas, à saúde pública, aos bens e pessoas, bem como os agravos infringidos aos recursos naturais considerados em si mesmo, ou seja, os ecossistemas. $\mathrm{O}$ artigo pretende demonstrar que há uma diferença entre danos ambientais e danos ecológicos e que, especificamente no Brasil, tal distinção não tem sido considerada, o que tem acarretado uma compreensão inadequada das características peculiares a serem observadas no tema da reparação de danos ecológicos. A distinção será feita com base na doutrina jurídica existente, examinando-a em suas manifestações nacional e internacional, buscando demonstrar que a separação entre (i) dano ambiental e (ii) dano ecológico é essencial para a identificação e definição das medidas de recuperação cabíveis. É evidente que, no contexto do artigo, a questão relativa à valoração econômica dos bens naturais e dos ecossistemas ocupará posição de destaque, motivo pelo qual merecerá compatível tratamento no artigo.

Uma vez estabelecidas as definições conceituais de dano ambiental e de dano ecológico, passar-se-á ao estudo das características específicas da recuperação dos danos ecológicos, em especial no que se refere aos seus limites e objetivos. Como se demonstrará, a recuperação de danos ecológicos é feita com base em solução técnica e não se confunde com uma repristinação absoluta ao status quo ante. Tal demonstração será promovida com base na legislação e na jurisprudência existente.

\section{DANOS AMBIENTAIS E DANOS ECOLÓGICOS}

Para que se possa avançar no sentido de uma compreensão adequada da intrigante questão da recuperação dos danos ao meio ambiente, faz-se necessário identificar os mecanismos jurídicos aptos a viabilizá-la. A proteção jurídica do meio ambiente no Brasil se faz por meio do Direito Ambiental e não do Direito Ecológico (ANTUNES, 2016); tal opção se fez devido ao fato de que no conceito de ambiente - tal como adotado no Brasil - estão compreendidos elementos da atividade econômica, social e ecológica. Assim, o Direito Ambiental contém o "direito ecológico", que, por sua vez, seria o direito voltado exclusivamente para a proteção à na- 
tureza que, como se sabe, não é a hipótese da ordem jurídica brasileira. Há, portanto, que se estabelecer os campos próprios do dano ambiental e do dano ecológico para que se possa, posteriormente, tratar da relevante questão da recuperação, do ponto de vista legal. José de Sousa Cunhal SENDIM (1998, p. 70) chama a atenção para o fato de que a expressão "danos causados ao meio ambiente" [danos ambientais] é característica do direito brasileiro, sendo, portanto, necessário que se observe como outras ordens jurídicas tratam do problema.

A Política Nacional do Meio Ambiente (Lei Federal n ${ }^{\circ} 6.938 / 1981$ - "PNMA"), muito embora não possua definição normativa de dano ambiental ou de dano ecológico, oferece uma indicação para o estabelecimento dos respectivos conceitos, ao definir (i) degradação da qualidade ambiental e (ii) poluição, conceitos que, combinados, podem levar a compreender o conceito de dano ambiental (ecológico).

A degradação da qualidade ambiental é a alteração adversa das características do "meio ambiente"; por sua vez, poluição é a degradação da qualidade ambiental que seja "resultante" de atividades que, direta ou indiretamente, (i) prejudiquem a saúde, a segurança e o bem-estar da população, (ii) criem condições adversas às atividades sociais e econômicas, (iii) afetem desfavoravelmente a biota, (iv) afetem as condições estéticas ou sanitárias do meio ambiente ou (v) lancem matérias ou energia em desacordo com os padrões ambientais estabelecidos. Em sede regulamentar, o Conselho Nacional do Meio Ambiente ("CONAMA"), estabeleceu, em sua Resolução $n^{0}$ 01/1986, o conceito de impacto ambiental que, de certa forma, reproduz o conceito de degradação ambiental, pois é "qualquer alteração" das propriedades físicas, químicas e biológicas do meio ambiente - no caso o meio físico - que tenha sido causada por qualquer forma de matéria ou energia resultante das atividades humanas, afetando, direta ou indiretamente, (i) a saúde, a segurança e o bem-estar da população, (ii) as atividades sociais e econômicas, (iii) a biota, (iv) as condições estéticas e sanitárias do meio ambiente ou (v) a qualidade dos recursos ambientais.

A poluição, todavia, é palavra polissêmica podendo ser juridicamente relevante ou irrelevante. No direito brasileiro é possível identificar, pelo menos, três modalidades de poluição (i) aquela em sentido estrito, (ii) o dano ambiental e (iii) o crime ambiental. (ANTUNES, 2015, p. 125).

É importante observar que, em alguns casos, a poluição - no sentido de desacordo com padrões ambientais pré-fixados - é admitida, como, por exemplo, no caso da chamada "zona de mistura", definida pela Reso- 
lução CONAMA n ${ }^{\circ}$ 430/2011 como "a região do corpo receptor, estimada com base em modelos teóricos aceitos pelo órgão ambiental competente, que se estende do ponto de lançamento do efluente e é delimitada pela superfície em que é atingido o equilíbrio de mistura entre os parâmetros físicos e químicos, bem como o equilíbrio biológico do efluente e o do corpo receptor, sendo específica para cada parâmetro."

Conforme foi visto acima, as normas brasileiras identificam, com segurança, duas modalidades de "danos ambientais". O primeiro é um dano reflexo, ou seja, dano que não atinge os recursos naturais propriamente ditos, mas que resultam reflexamente de agravos aos recursos naturais. Como exemplo, figure-se uma comunidade que tenha sofrido interrupção no abastecimento de água em função de grave poluição nos mananciais. A falta de água e suas consequências econômicas e sociais são diretamente derivadas da poluição. O segundo é o dano ao ambiente em si, cuidandose, nesse caso, de um dano ambiental puro.

No que se refere à recuperação e à sua quantificação, os caminhos serão bastante diversos. Por questões metodológicas, adota-se o conceito de dano ecológico para os danos causados especificamente ao ambiente e aos recursos naturais. A distinção conceitual, ora esposada, justifica-se, na medida em que as vantagens para a adequada compreensão das particularidades e características próprias de cada uma das modalidades são evidentes, facilitando a compreensão do objeto que se busca estudar, pois, como já foi registrado, há “uma confusão escusável” (ROMI, 2010, p. 148) entre os danos ambientais e os danos ecológicos.

Com efeito, sabe-se que o meio ambiente é composto por bens de diferentes classes, regimes dominiais e tantos outros elementos que necessitam ser claramente identificados e definidos para que se possa ter certeza sobre a espécie do dano em questão. Para que se evite a "confusão escusável", não se pode misturar os danos à saúde com os que afetam as condições estéticas do meio ambiente, ou com a destruição de manguezais ou mananciais, por exemplo. (ANTUNES, 2015, p. 126).

Uma excelente clarificação dos conceitos de dano ambiental e dano ecológico foi feita pelo Tribunal Central Administrativo Sul português ${ }^{1}$, posteriormente confirmada pelo Superior Tribunal Administrativo ${ }^{2}$. Entendem as cortes administrativas portuguesas que o dano ecológico é

1 Tribunal Central Administrativo Sul 2º Juízo, 05849/10. Data 07/02/2013, Relator Paulo Pereira Gouveia, disponível em: < https://goo.gl/RmbtMV>. Acesso em: 02 abr. 2017.

2 Superior Tribunal Administrativo, $1^{a}$ Seção, 0978/13, Data 20/02/2014, Relator São Pedro, disponível em: <https://goo.gl/4FNxcR>. Acesso em: 02 abr. 2017. 
constituído por "lesões intensas" produzidas ao sistema ecológico, independentemente de violação a direitos individuais, tratando-se, portanto, de "lesão causada a um recurso natural, susceptível de causar uma afetação significativa do equilíbrio do bem jurídico ambiente ou património natural e da sua interação". Por sua vez, o dano ambiental é aquele causado ao meio ambiente e que gera "repercussões na esfera patrimonial de um particular". Fernando Reis CONDESSO (2014, p. 211), ao analisar decisões das cortes administrativas portuguesas, ressalta o fato de que o dano ecológico não engloba a ofensa a interesses difusos, coletivos ou individuais, os quais, segundo a Corte, assemelham-se às violações aos direitos subjetivos dos cidadãos, motivo pelo qual não se justifica o seu tratamento em conjunto com danos infringidos aos bens naturais.

O dano ambiental, assim, é a repercussão do dano causado aos bens naturais na esfera particular do cidadão ou da pessoa jurídica. Dessa forma, por ser também uma violação de direitos subjetivos, caberá indenização no que diz respeito aos direitos subjetivos de terceiros.

\section{VALOR ECONÔMICO DO RECURSO AMBIENTAL (ECOLÓ- GICO)}

Estabelecer um preço ou valor econômico para bens aos quais se atribui valor "inestimável" é algo que, culturalmente, soa repugnante. Todavia, diariamente preços e valores são atribuídos a bens de valor inestimável como é o caso da vida humana. E mais: tais valores podem variar conforme a condição jurídica do falecido. Assim, se o cidadão faleceu na condição de aposentado pela previdência social brasileira, a pensão por morte devida aos seus familiares seria de um valor; caso não fosse aposentado, o valor seria diferente ${ }^{3}$.

Toda a indústria de seguros se baseia na fixação de valores indenizatórios o que, na prática, é a definição de valores determinados para bens tidos por "inestimáveis". Em relação ao meio ambiente não é diferente. A questão tem, evidentemente, um forte conteúdo moral que está relacionado a quanto se deve gastar para a proteção do meio ambiente (ACKERMAN; HEINZERLING, 2004, p. 9). O fato é que não só a proteção ao meio ambiente tem um custo, mas também a recuperação do meio ambiente degradado. Partindo-se dessa premissa, faz-se fundamental estabelecer critérios que possam servir de instrumentos para que tais custos

3 Para mais informações, conferir: <https://goo.gl/q6dAhj>. Acesso em: 08 abr. 2017. 
sejam adequadamente identificados.

A atribuição de valor econômico aos recursos naturais é tarefa da maior relevância, pois é através dela que se pode decidir medidas de recuperação ou até mesmo indenizações pecuniárias devidas em função de danos ao ambiente. No caso específico do Brasil, não se pode olvidar que o meio ambiente é, por força de lei, considerado como patrimônio público (PNMA, art. $2^{\circ}$, inciso I). Ademais, não raras vezes, os órgãos de controle ambiental, no uso de suas atribuições, determinam a recomposição do meio ambiente lesado por alguma ação deletéria, necessitando, portanto, ter valores pecuniários capazes de oferecer alguma direção para a ação administrativa. Assim, o Valor Econômico dos Recursos Ambientais ("VERA") é objeto de uma formulação que contempla (i) o Valor de Uso ("VU") e (ii) o Valor de Não Uso ("VNU"), resultando na seguinte equação (MOTTA, 2004, p.94):

$$
\mathrm{VERA}=(\mathrm{VUD}+\mathrm{VUI}+\mathrm{VO})+\mathrm{VE}
$$

Em conformidade com Ronaldo Seroa da MOTTA, o valor econômico dos recursos ambientais "não é observável" (2004, p. 93), pois não existe um sistema de preços que reflita o seu custo de oportunidade, sendo que o seu "consumo" se realiza por meio do uso e do não uso. O uso e o não uso se repartem em (i) Valor de Uso Direto ("VUD”), que é o atribuído a um recurso ambiental pela sua utilização direta, podendo se dar por extração, visitação ou outra forma de produção ou consumo direto; (ii) Valor de Uso Indireto ("VUI"), aquele atribuído a um recurso ambiental quando o benefício do seu uso deriva de suas funções ecológicas propriamente ditas; (iii) Valor de Opção ("VO"), aquele atribuído à conservação dos recursos que podem se encontrar ameaçados, assegurando usos direto e indireto em futuro próximo. Por sua vez, o Valor de Não Uso, Passivo ou Valor de Existência ("VE") é aquele dissociado do uso, em conformidade com concepções morais, culturais, éticas ou de outra ordem, que impliquem em sua não utilização, independentemente de seu valor para a sociedade ou para os indivíduos.

Em síntese, José de Sousa Cunhal SENDIN (1998, p. 87) identifica três classes de valor (i) o de uso atual (use value), aquele que os consumidores atribuem ao uso (atual) de um recurso ambiental - i. e., o valor do ambiente como benefício potencial; e (ii) o de opção (option value) - i.e., o valor do ambiente como benefício potencial; e (iii) o de existência 
(existence value) - i.e., o valor que as pessoas atribuem à existência de um recurso, independentemente do seu uso in situ.

Evidentemente existem outras fórmulas e metodologias (CARVALHO, 2008) que podem ser empregadas para a valoração dos danos ecológicos. No caso específico de derramamento de óleo em recursos hídricos, a Companhia Ambiental do Estado de São Paulo ("CETESB") desenvolveu uma fórmula que leva em consideração os seguintes fatores: (i) volume derramado, (ii) grau de vulnerabilidade da área atingida, (iii) toxicidade do produto, (iv) persistência do produto no ambiente e (v) mortalidade de organismos. Tais fatores são agrupados em uma fórmula, divididos em níveis, atribuindo-se a cada nível um determinado peso, conforme a intensidade do risco ou dano gerado, com variação de 0 a 0,5 . A formulação pode ser resumida na seguinte equação:

$$
\text { Valor }(\$)=10^{(4,5+\mathrm{x})}
$$

Onde X é o somatório dos pesos atribuídos conforme a gravidade do evento danoso.

Considerando-se que a restauração natural nem sempre é possível, a valoração pecuniária do ambiente natural lesado tem o relevante papel de contribuir para (i) viabilizar financeiramente alguma forma de compensação, quando impossível qualquer reparação - poluição sonora, por exemplo e (ii) tornar certa a indenização, quando cabível (LEITE e ALMEIDA, 2005, p. 81).

\subsection{Valor econômico dos bens ambientais no direito positivo}

A PNMA, desde sua redação original, já admitia a possibilidade de valoração econômica dos recursos naturais, haja vista que já previa em seu artigo $4^{\circ}$, inciso VII, a possibilidade de imposição "ao usuário, de contribuição pela utilização de recursos ambientais com fins econômicos." Todavia, tal contribuição jamais foi regulamentada.

Posteriormente, a Política Nacional de Recursos Hídricos (Lei Federal no 9.433/1997 ou "PNRH"), expressamente reconheceu que "a água é um recurso natural limitado, dotado de valor econômico" e, como consequência, estabeleceu como um de seus principais instrumentos a co- 
brança pelo uso dos recursos hídricos, com o objetivo de (i) reconhecer a água como bem econômico e dar ao usuário uma indicação de seu real valor, (ii) incentivar a racionalização do uso da água e (iii) obter recursos financeiros para o financiamento dos programas e intervenções contemplados nos planos de recursos hídricos.

A compensação ambiental ("CA") prevista na Lei do Sistema Nacional de Unidades de Conservação (Lei Federal no 9.985/2000 ou "SNUC") é devida nos casos de licenciamento ambiental de empreendimentos de significativo impacto ambiental e, com fundamento no estudo de impacto ambiental, gera para o empreendedor a obrigação de apoiar a implantação e a manutenção de unidade de conservação do Grupo de Proteção Integral. O legislador arbitrou um valor não inferior a meio por cento dos custos do projeto como equivalente pecuniário do dano ecológico produzido. A definição do valor devido a título de compensação ambiental, de acordo com o disposto no Decreto Federal no 4.340/2002, é feita mediante a aplicação de uma fórmula que tem como parâmetros fundamentais o chamado grau de impacto ("GI") que deverá ser calculado segundo uma fórmula complexa, trazida pelo Decreto Federal n ${ }^{0}$ 6.848/2009, e o valor de referência ("VR"). Assim, a fórmula é:

\section{$\mathrm{CA}=\mathrm{VR} \times \mathrm{GI}$}

$\mathrm{VR}=$ somatório dos investimentos necessários para implantação do empreendimento, não incluídos os investimentos referentes aos planos, projetos e programas exigidos no procedimento de licenciamento ambiental para mitigação de impactos causados pelo empreendimento, bem como não são incluídos os encargos e custos incidentes sobre o financiamento do empreendimento, inclusive os relativos às garantias, e os custos com apólices e prêmios de seguros pessoais e reais;

$\mathrm{GI}=$ Grau de Impacto nos ecossistemas, podendo atingir valores de 0 a $0,5 \%$.

Também na Política Nacional de Resíduos Sólidos (Lei Federal $n^{\circ}$ 12.305/2010 "PNRS") há um forte reconhecimento do valor econômico do ambiente, ao estabelecer que os resíduos sólidos são economicamente importantes, vez que uma de suas diretrizes mais relevantes é "o reconhecimento do resíduo sólido reutilizável e reciclável como um bem econômi- 
co e de valor social, gerador de trabalho e renda" (art. $6^{\circ}$, inciso VIII). Evidentemente, ao se valorizar o resíduo, diminui-se o seu descarte irregular no ambiente, reduzindo-se os custos ambientais da sociedade.

\subsubsection{Poder Judiciário e Valoração do dano ecológico}

O cálculo de valores pecuniários relativos aos bens ecológicos, longe de ser questão puramente teórica é, isto sim, matéria de grande importância prática. No Brasil tem havido um crescente número de decisões judiciais sobre o tema. E, como regra, tais decisões têm reconhecido as dificuldades relativas à valoração dos bens naturais, adotando-se soluções pragmáticas e casuísticas. Tais decisões partem do pressuposto de que "[n]ão há previsão legal dos parâmetros para a valoração de danos aos recursos naturais, sendo que a valoração acaba tendo grande influência subjetiva." (Tribunal Regional Federal da $4^{a}$ Região, Apelação Cível, Processo 0004182-74.2001.404.7201, 4ª Turma, Relator Luís Alberto D`Azevedo Aurvalle).

O reconhecimento da inexistência de regulamentação legal - com exceção clara para a CA - e da grande influência subjetiva, tem levado os tribunais, em especial o Tribunal de Justiça de São Paulo e o Tribunal Regional Federal da 3a Região ("TRF-3") à utilização da metodologia desenvolvida pela CETESB, ainda que tal metodologia não conste de norma legal ou administrativa; todavia, como não poderia deixar de ser, cuida-se de aplicação tópica e casuística.

Em relação à discussão da metodologia para a valoração dos danos ambientais, o Tribunal de Justiça de São Paulo ("TJSP") não adota posicionamento homogêneo, mas leva em consideração as peculiaridades do caso: "[o]s valores foram obtidos mediante aplicação da "Metodologia para valoração dos danos ambientais"; no entanto, método diverso deve ser utilizado por se considerar o mais adequado para fins indenizatórios." (TJSP, 2007981-95.2013.8.26.0000, Relator: Ruy Alberto Leme Cavalheiro; Comarca: Ribeirão Bonito; Órgão julgador: $1^{\text {a }}$ Câmara Reservada ao Meio Ambiente; Data do julgamento: 04/12/2014; Data de registro: 05/12/2014). Nas razões de decidir, o relator alertou para o fato de que muito embora o cálculo do quantum indenizatório se encontre baseado na metodologia da Secretaria de Estado de Meio Ambiente, esta metodologia não é

a mais adequada consoante entendimento consolidado nesta Câmara. O dano, apesar de certo, é incalculável, sendo praticamente impossível delimitar o alcance 
dos prejuízos decorrentes da queimada ocorrida. Aquilo que foi lançado no ar, ou os problemas de saúde e, ainda, as mortes ocasionadas pelo evento, quer de seres humanos ou animais, não são mensuráveis por meio de perícia tradicional.

A metodologia que tem prevalecido, seja administrativa, seja judicialmente, é a adotada pela CETESB que, no entanto, repita-se, é uma mera proposta de metodologia a ser aplicada, sobretudo, em casos de derramamento de óleo no mar. O Tribunal Regional Federal da $3^{\text {a }}$ Região, em diversas oportunidades, tem decidido casos concretos com base na metodologia de valoração de danos ecológicos utilizada pela agência ambiental paulista.

É mantida a condenação da (...) no pagamento de indenização pelos danos causados ao meio ambiente, apurada em liquidação por arbitramento, correspondente ao valor mínimo da "Proposta de Critério para Valoração Monetária de Danos Causados por Derrames de Petróleo ou de seus Derivados no Ambiente Marinho", elaborada pela CETESB; e revertida ao Fundo de Reparação de Direitos Difusos Lesados

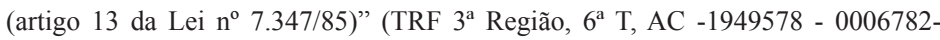
42.2011.4.03.6103, Rel. Desembargador Federal Johonsom di Salvo, e-DJF3 Judicial $1: 19 / 11 / 2015)$

É interessante que se observe que o TRF--3 tem se utilizado de critérios de equidade para definir o valor monetário equivalente aos danos ecológicos.

O juízo de origem condenou as rés ao pagamento de $\mathrm{R} \$ 40.000,00$ (quarenta mil) reais a título de indenização por dano ambiental. O voto vencido, por sua vez, majorou o montante para $\mathrm{R} \$ 158.489,32$, considerado desproporcional para reparar os danos ambientais no caso concreto, ao fundamento de que a área do acidente já se encontrava em avançado estágio de degradação em razão da própria atividade portuária, de forma que o voto vencedor estabeleceu a indenização em R \$ 80.000,00 (oitenta mil reais). - Se a lei não oferece critérios para a fixação do montante da indenização por dano ambiental, nada obsta à aplicação dos critérios estabelecidos na metodologia CETESB, atendidas, evidentemente, as particularidades do caso em exame e observados os princípios da razoabilidade e da proporcionalidade. Não 
obstante as críticas que a ela se fazem, não a desqualificam como um instrumento técnico adequado para estimar a quantificação monetária do valor da indenização. A adoção da metodologia CETESB justifica-se, ainda, por traduzir medida que evita a imposição aleatória do quantum passível de indenização, pois funciona como um padrão matemático para a valorização monetária de danos causados por derramamento de petróleo ou de seus derivados no mar, desde que precisamente observados os seus cinco aspectos relevantes (volume, vulnerabilidade da área, toxicidade do produto, persistência do produto e mortalidade de organismos), aos quais, divididos em níveis, foi atribuído peso correspondente, de acordo com a severidade do risco ou dano gerado, que varia de 0 a 0,5 , e ressalvada a necessidade de adequação do valor apurado às peculiaridades do caso e atendidos os critérios da razoabilidade e proporcionalidade à ofensa real ao estuário. Precedentes desta corte. - Conforme minudentemente explicitado no voto vencido, o cálculo da indenização com base na fórmula estabelecida pela CETESB representa critério técnico-científico que incorpora a razoabilidade e a proporcionalidade, de modo que dispensa e deve prevalecer sobre qualquer outra valoração". (TRF $3^{\mathrm{a}}$ Região, $2^{\mathrm{a}}$ SEÇÃO, EI- 1331362 - 0006757-75.2001.4.03.6104, Rel. Juiza Convocada Leila Paiva, e-DJF3 Judicial 1: 23/06/2016 ).

\section{RECUPERAÇÃO DOS DANOS ECOLÓGICOS}

A segunda metade do século XX atribuiu relevante valor ao meio ambiente, o que logo deu origem ao Direito Ambiental, que passou a possuir cada vez mais um papel significativo na ordem jurídica. Em poucos anos, a questão ambiental assumiu status constitucional em diversos países, inclusive no Brasil. Por tal circunstância, a recuperação de danos causados ao ambiente natural ganhou status e relevância inauditos.

\subsection{A recuperação dos danos ecológicos como obrigação constitucio- nal}

A responsabilidade por danos ao meio ambiente e a sua consequente recuperação, como se sabe, no Brasil, têm assento diretamente na Constituição da República Federativa do Brasil ("CRFB"), mais precisamente no artigo $225, \S 3^{\circ}$. Contudo, ainda no regime constitucional precedente, a legislação ordinária já dispunha sobre o tema (artigo $14, \S 1^{\circ}$, da PNMA).

A constitucionalização da proteção ao meio ambiente adotada 
pelo Brasil, em 1988, representou a adesão do País a uma tendência característica das modernas constituições, como é o caso das constituições da Argentina (artigo 41), Colômbia (artigo 79), França (Lei Constitucional - Carta do Ambiente, artigo 4º), Espanha (artigo 45), do Paraguai (artigo $7^{\circ}$ ) e de Portugal (artigo 66) ${ }^{4}$, por exemplo. Como resultado da proteção ao meio ambiente estabelecida em tais constituições, existe um sistema de reparação dos danos ao meio ambiente que está fundado basicamente na recomposição natural do ambiente danificado, sendo a indenização pecuniária uma hipótese prevista somente nos casos de impossibilidade da recomposição natural.

Todavia, tal compreensão não é tranquilamente aceita, pois a alta carga emocional envolvida nas questões relativas à proteção do meio ambiente tende a ver como obrigatória a indenização pecuniária que, na prática, teria a função de mais uma pena a ser imposta ao causador de danos ao ambiente. Todavia, não se pode deixar de anotar, com Carla Amado GOMES (2014), que talvez esse seja um dos "equívocos" do direito ambiental, pois está excessivamente focado em condutas repressivas ex post facto e pouquíssimo empenhado na prevenção. Assim, segundo a autora, "conceder relevo ao instituto da responsabilidade civil pode parecer contraproducente." (GOMES, 2014, p. 239)

Como se demonstrará, a recomposição de danos ambientais e a recuperação natural, tal como tratadas na Constituição, não se confundem com o retorno do ambiente a um mítico estado de pureza natural, existente independentemente da presença humana que, como se sabe, jamais existiu. É necessário que se tenha bem claro que é uma "adorável fantasia" pensar-se em ecossistemas sem a presença humana. (MORAN, 2011, p. 9)

\subsection{A recuperação dos danos ecológicos no direito infraconstitucional}

Uma vez que já foram explicitados os padrões constitucionais, analisar-se-á a questão sob a ótica da legislação infraconstitucional.

\subsubsection{Direito brasileiro}

A recuperação dos danos ecológicos e a recomposição da biota

4 Para acesso à íntegra das Constituições, conferir: <https://www.constituteproject.org/>. Acesso em: 14 abr. 2017. 
degradada, nos termos do direito positivo brasileiro, são feitas sob o acompanhamento e supervisão dos órgãos de controle ambiental, conforme as suas respectivas esferas de competência. Assim, a recuperação natural dos danos ecológicos será aquilo que o órgão de controle ambiental disser que é. Essa é uma constatação que não deve causar estranheza, pois decorre de uma interpretação lógica de disposições expressamente previstas na CRFB. No caso, merece ser observado o $\S 2^{\circ}$, do artigo 225 da CRFB que, literalmente, determina, em relação à atividade minerária, a obrigatoriedade de recuperar "o meio ambiente degradado, de acordo com solução técnica exigida pelo órgão público competente, na forma da lei." Ainda que a menção seja explicitamente referente ao caso da mineração, o fato é que o modelo é aplicável a todo e qualquer dano ecológico.

Assim, a recuperação ecológica é submetida a uma avaliação do órgão de controle ambiental que determina os seus limites. Cuida-se de uma medida de proporcionalidade entre o nível de recomposição da biota afetada e a sensível questão dos custos das atividades reparatórias do ambiente. Ademais, é necessário que se estabeleça qual é o limite ótimo de recuperação, pois efetivamente as medidas de recuperação natural devem, necessariamente, deixar espaço para que a natureza, após um estímulo planejado e adequado ao caso concreto - as medidas promovidas no processo de recuperação -, siga o seu curso independentemente da ação humana. Os bens naturais não podem ser substituídos por outros iguais, pois um pássaro morto não retornará à vida; logo, o que se busca é um equivalente, o mais aproximado possível do que foi perdido.

O direito brasileiro, infelizmente, não deu ao tema a necessária relevância, sendo franciscano no cuidar do assunto com pouquíssimas normas dedicadas à matéria - a maior parte são meros regulamentos administrativos. Como se sabe, a PNMA tem como um de seus objetivos a "recuperação da qualidade ambiental" (artigo $2^{\circ}$ ), sendo a "recuperação de áreas degradadas" (artigo $2^{\circ}$, VIII) um dos seus vetores fundamentais.

Áreas degradas, nos termos da PNMA, são aquelas nas quais tenha ocorrido uma "alteração adversa das características do meio ambiente" (artigo $3^{\circ}$, II). Entretanto, a PNMA não traz qualquer indicação do sentido a ser atribuído à recuperação de áreas degradadas, sendo, no particular, uma norma em aberto. Para que se possa prosseguir, julga-se conveniente trazer a lume o conceito de degradação ambiental, que é: 
de agentes externos a ele. Processo conceitualmente caracterizado pela perda ou diminuição de matéria, forma, composição, energia e funções de um sistema natural por meio de ações antrópicas (SILVA et al, 1999, p. 73).

Conceitualmente, recuperação ambiental é o "processo artificial de recomposição de determinadas áreas degradadas ao seu estado natural original" (SILVA et al, 1999, p. 195), fazendo-se a ressalva acerca da impossibilidade de voltar ao passado.

A Lei no 9.605, de 12 de fevereiro de 1998 ("Lei de Crimes Ambientais"), utiliza os termos (i) composição, (ii) recuperação e (iii) reparação quando se refere aos danos ecológicos e às áreas degradadas. É importante ressaltar que a norma prevê que a reparação pode ser (i) espontânea ou (ii) forçada, acarretando consequências jurídicas diversas. No campo penal, a reparação espontânea do dano tem como uma de suas consequências mais relevantes a atenuação da pena imposta ao réu (artigo 14, II). Registre-se, todavia, que a norma admite a "limitação significativa da degradação ambiental", o que tem sido entendido, do ponto de vista da aplicação da lei penal, como "reparação parcial do dano causado" (GOMES; MACIEL, 2015, p. 58).

O artigo 27 da Lei de Crimes Ambientais admite uma "prévia composição dos danos", conceito de natureza processual, que implica na celebração de um acordo entre réu e acusação com vistas à reparação dos danos, o que deverá ser feito, conforme plano aprovado pela autoridade ambiental; ou seja, a entidade pública, dotada de atribuição para as questões relativas à qualidade do ambiente e sua recuperação, notadamente a responsável pelo licenciamento ambiental, conforme se pode depreender da combinação do artigo 10 da PNMA com os artigos $2^{\circ}$, I, art. $7^{\circ}$, inciso XIV, art. $8^{\circ}$, inciso XIV e artigo $9^{\circ}$, inciso XIV da Lei Complementar $n^{\circ}$ 140, de 8 de dezembro de 2011. Ainda aqui, a ideia da recomposição do meio ambiente lesado é a primordial, pois "a preocupação primeira foi com o restabelecimento do ambiente lesado" (GOMES; MACIEL, 2015, p. 97). Há, contudo, uma monetarização do dano ecológico no artigo 20, da Lei de Crimes Ambientais, que determina que a sentença deverá - sempre que possível - estipular o "valor mínimo" equivalente ao dano sofrido pelo meio ambiente (dano ecológico).

Como se pode perceber, ainda que presentes várias menções à recuperação e restauração ambiental, a ordem jurídica nacional carecia de definições normativas para os termos, o que veio a ser superado pela Lei 
do SNUC que, em seu artigo $2^{\circ}$, incisos XIII e XIV, estabeleceu os conceitos jurídicos de recuperação e de restauração, sendo (i) recuperação a "restituição de um ecossistema ou de uma população silvestre degradada a uma condição não degradada, que pode ser diferente de sua condição original" e (ii) restauração a "restituição de um ecossistema ou de uma população silvestre degradada o mais próximo possível da sua condição original." Vê-se, portanto, que a recuperação de danos ecológicos, diferentemente do que se poderia pensar, não corresponde a uma abstrata restituição do meio natural lesado a um estado original ideal sobre o qual, na maioria das vezes, inclusive, não há sequer uma informação técnica segura. Trata-se, como se vê, de uma recuperação até determinado estágio, considerado tecnicamente adequado pelo órgão de controle ambiental.

No particular, faz-se necessário retornar ao $\S 2^{\circ}$, do artigo 225 da CRFB, o qual expressamente - repita-se - estabelece que, em relação à atividade minerária, há a obrigatoriedade de recuperação do "meio ambiente degradado, de acordo com solução técnica exigida pelo órgão público competente, na forma da lei." Dessa forma, a recuperação ambiental é aquilo que o órgão ambiental considerar como tal, conforme clara autorização constitucional. Aliás, diversas constituições estaduais, como os Textos Constitucionais dos estados de Minas Gerais (artigo 214) e São Paulo (artigo 190) adotam a mesma concepção. Todavia, o órgão de controle ambiental não é livre para considerar uma área degradada como recuperada, sendo limitado em sua discricionariedade pelos resultados concretos produzidos pela implementação de determinado projeto técnico de recuperação. Da mesma forma, o órgão de controle ambiental não pode, discricionariamente, definir programas de recuperação que não guardem uma adequada proporção, seja com o dano causado, seja com a capacidade de pagamento de seu causador.

\subsubsection{Programa de Recuperação de Areas Degradadas - PRAD}

De acordo com aquilo que já foi, exaustivamente, visto neste artigo, a recomposição integral do meio ambiente às condições anteriores às da ocorrência do dano que se busca recuperar é uma questão com caráter puramente retórico - ou, simbólico -, pois não é esta a determinação constitucional, nem a prática administrativa. A recuperação é uma solução técnica definida pelo órgão de controle ambiental, conhecida como Plano 
de Recuperação de Áreas Degradadas (PRAD). Os diferentes órgãos de controle ambiental são dotados de regras próprias para a definição do procedimento a ser adotado pelo causador do dano - ou seus sucessores - para a recuperação das áreas lesadas. O Instituto Brasileiro do Meio Ambiente e dos Recursos Renováveis (Ibama) disciplinou a matéria pela Instrução Normativa IBAMA n ${ }^{\circ}$ 04, de 13 de abril de 2011 (IN n 0 04/2011). É importante observar que a $\mathrm{IN} \mathrm{n}^{\circ} 04 / 2011$ pragmaticamente identifica duas categorias de áreas passíveis de recuperação, (i) as degradadas e (ii) as alteradas ou perturbadas. A área degradada é aquela "impossibilitada de retornar por uma trajetória natural, a um ecossistema que se assemelhe a um estado conhecido antes, ou para outro estado que poderia ser esperado"; já a área alterada ou perturbada é aquela que "após o impacto, ainda mantém meios de regeneração biótica, ou seja, possui capacidade de regeneração natural".

O Superior Tribunal de Justiça (STJ), em várias oportunidades, tem decidido questões relativas ao PRAD e ao seu papel na recuperação de danos ecológicos. O tribunal tem entendido que a recomposição ao status quo ante deve ser feita "na medida do possível, do status quo ante das áreas delimitadas" (STJ, REsp 138.208/PE, Relator Ministro Herman Benjamin, $2^{\mathrm{a}}$ Turma, DJe 12/09/2016). A relevância do PRAD é de tal monta que ele é considerado um limitador da discricionariedade administrativa, sobretudo quando se trata da redução de multas ambientais:

(...)[C]abimento da redução da multa nos casos em que há comprovação de que a autoridade administrativa competente verificou o cumprimento integral do PRAD e que a recuperação decorreu das ações tomadas pelo infrator e não devido a outros fatores.... 4. Nesse contexto, correto o acórdão ao manter a redução da multa, haja vista o cumprimento integral das obrigações assumidas para a reparação do dano atestado pela FATMA, consoante constatado pelo juízo a quo. (STJ, REsp 124.8649/ SC, $2^{\text {a }}$ Turma, Relator Ministro Mauro Campbell, DJe 24/08/2011).

Em discussão relativa ao cumprimento do PRAD e à concomitante incidência de indenização pecuniária devida em função de danos ecológicos, entendeu a $2^{\mathrm{a}}$ Turma do STJ que:

O Superior Tribunal de Justiça tem externado o entendimento de que as ações de 
obrigação de fazer podem ser cumuladas com as indenizatórias; e que nem sempre a recomposição da área degradada ou o saneamento do dano provocado ilide a necessidade de indenização. Todavia, esse entendimento não implica a conclusão de que, sempre, será devida a indenização, pois, quando é possível a completa restauração, sem que se verifique ter havido dano remanescente ou reflexo, não há falar em indenização. (...). (STJ, REsp 1382999/SC, $2^{\text {a }}$ Turma, Relator Ministro Humberto Martins, Dje 18/09/2014).

\subsubsection{Direito Estrangeiro}

Nesta altura é importante demonstrar que, em termos legislativos, vários países adotam normas assemelhadas às brasileiras. Na Argentina, a Lei Nacional $\mathrm{n}^{\circ} 25.675$, de 27 de novembro de 2002, voltada à proteção do meio ambiente e que é a equivalente à PNMA brasileira, estabelece, em seu artigo 28, a responsabilidade objetiva pelo dano ambiental, determinando que o responsável deverá restabelecer o meio ambiente até o seu "estado anterior" à produção do dano, sendo a indenização devida na hipótese em que a recomposição não seja "tecnicamente factível".

No mesmo sentido vai a legislação chilena que, na Lei n ${ }^{\circ} 19.300$, de 09 de março de 1994, com nova redação dada em 01 de junho de 2016, em seu artigo 53, somente admite o ajuizamento de ação reparatória de danos ambientais nas hipóteses em que o causador do dano não tenha obedecido as diretrizes do órgão de controle ambiental para a recomposição do ambiente lesado. Igualmente ocorre no Peru, com a Lei $n^{\circ} 28.611$, Lei Geral do Ambiente, que, em seu artigo IX, estabelece a obrigatoriedade "inescusável" de restaurar, reabilitar ou reparar o dano ambiental e, nas hipóteses de impossibilidade de fazê-lo, a compensá-los.

$\mathrm{Na}$ União Europeia, a reparação dos danos ecológicos se faz de três formas básicas, segundo as normas contidas na Diretiva 2004/35/CE, a saber: (i) primária, (ii) complementar e (iii) compensatória. A reparação primária visa à restituição dos recursos naturais ao seu estado inicial ou "aproximado". A complementar busca assegurar um nível de recursos naturais e ou serviços, ainda que em outro local, similar ao que teria sido proporcionado se o local do dano tivesse retornado ao seu estado inicial. Já a compensatória busca "compensar" a perda transitória de recursos naturais e serviços naturais, enquanto a recuperação não ocorre. Caracteriza-se por uma série de melhorias suplementares de habitat naturais, espécies protegidas, água, seja no local danificado, seja em local alternativo. 
Portugal incorporou as normas da Diretiva ao seu direito interno por meio do DL n. ${ }^{\circ}$ 147/2008, de 29 de julho. As medidas de recuperação, de acordo com o artigo 15, devem ser implementadas pelo responsável pelo dano. Ele deverá, independentemente de notificação da autoridade ambiental, adotar todas as medidas para o controle da situação e, na medida do possível, "controlar, conter, eliminar ou gerir os elementos contaminantes pertinentes e quaisquer outros fatores danosos". Ultrapassada a primeira fase do enfrentamento do dano, o seu responsável dará início às medidas de reparação pertinentes. Evidentemente que o órgão de controle ambiental possui ampla discricionariedade para investigar os fatos, determinar medidas de reparação suplementares que julgue conveniente e, inclusive, executar atos reparatórios às expensas do causador do dano.

Em relação aos danos causados à água, às espécies e habitat naturais protegidos, a norma estabelece três modalidades a serem adotadas, a saber: (i) a reparação primária: qualquer medida de reparação que restitui os recursos naturais e ou serviços danificados ao estado inicial, ou os aproxima desse estado; (ii) reparação complementar: qualquer medida de reparação tomada em relação aos recursos naturais e/ou em relação a serviços para compensar pelo fato de a reparação primária não resultar no pleno restabelecimento dos recursos naturais e/ou dos serviços danificados e (iii) a reparação compensatória: qualquer ação destinada a compensar perdas transitórias de recursos naturais e/ou de serviços verificadas a partir da data de ocorrência dos danos até a reparação primária ter atingido plenamente os seus efeitos.

Na França, que, assim como Portugal, adotou as normas contidas na Diretiva 2004/35/CE, em seu Código do Ambiente, estabelece-se o mesmo leque de medidas reparatórias. Veja-se que as diferentes medidas de reparação a serem adotadas são sugeridas pelo responsável pela recuperação do dano e aprovadas pela autoridade ambiental. Tal sugestão se faz por meio de um plano específico que, no Brasil, como visto, é conhecido como PRAD; confira-se em Eve Truilhé-MARENGO (2015, p. 248) e Philippe MALINGREY( 2016, p. 221).

Logo, a reparação ecológica não é sinônimo de reversão total ao estado anterior ao fato lesivo, como fica muito claro nos comandos normativos e legais. Vê-se, portanto, que as normas não determinam a repristinação do ambiente ao seu estado original, até mesmo porque isso somente poderia ocorrer, em tese, com a existência de base de dados sobre o estado do ambiente em momento anterior à ocorrência do fato lesivo. $\mathrm{O}$ que se 
busca é uma "aproximação" ao estado anterior." (RESP_201301228700, Ministro HUMBERTO MARTINS, DJe:18/09/2014) .

É importante ressaltar que a recuperação natural é um conceito que não se confunde com uma regeneração plena e total do ambiente. Isso é assim, na medida em que, conforme a velha lição de Heráclito de Éfeso, não se bebe água duas vezes no mesmo rio, pois a vida está em constante fluxo. Aliás, François OST (1995, p. 109) - na mesma linha - demonstra a impossibilidade lógica do retorno ao status quo ante, pois, "a natureza, como a história, nunca se repete; é apenas ao nível da percepção humana que se forma a impressão de retorno da mesma".

As dificuldades concretas para a quantificação monetária dos danos e para a definição de medidas reparatórias fizeram com que, paulatinamente, fossem sendo estabelecidas medidas inovadoras, tais como os fundos ambientais.

\section{DOUTRINA JURÍDICA E RECUPERAÇÃO DE DANOS ECO- LÓGICOS}

Uma vez que já foram apontados os marcos legais relativos à matéria, cumpre que se examine a interpretação doutrinária relativa ao direito posto. Conforme se verá, as vozes doutrinárias, quase que à unanimidade, têm considerado que a reparação dos danos ecológicos deve ser feita inicialmente pela recuperação natural, a qual consiste no emprego de técnicas e no monitoramento de sua efetividade, com vistas a permitir que o ambiente danificado siga um caminho de recuperação orgânico, o qual deverá ser monitorado pelo causador do dano, sob a supervisão do órgão de controle ambiental. Tal recuperação natural, na realidade jurídico-administrativa nacional é feita, primordialmente, mediante a execução de um PRAD, (cf. IN no 04/2011) que é elaborado pelo responsável pela recuperação da área degradada e submetido ao órgão de controle ambiental, em geral o responsável pelo licenciamento ambiental. Com efeito, não se pode confundir a recuperação de danos ecológicos com "uma moderna versão da Lex Talionis." (ANTUNES, 2015, p. 164).

Na mesma linha, José Rubens Morato LEITE e Patryck de Araújo AYALA (2010, p. 210) sustentam ser a melhor forma de reparação do dano ambiental [ecológico], "isto é, a ideal”, a utilização de técnicas de recuperação ou recomposição do bem lesado, fazendo-se cessar, também, as práticas lesivas ao meio ambiente, no caso concreto. Assim, conforme 
Fabiano Melo Gonçalves de OLIVEIRA ( 2010, p. 152), a reparação dos danos ambientais se biparte em (i) reparação in natura e (ii) indenização, observando a existência de uma ordem de preferência, o que significa dizer que a indenização somente será devida na hipótese de impossibilidade da recuperação natural. Não se trata, todavia, de voz isolada, pois, de igual teor é o entendimento esposado por Danny Monteiro da SILVA (2006, p. 188), vez que a recuperação natural somente deverá ser abandonada se "comprovado ser tecnicamente impossível obter o padrão ambiental anterior ao acontecimento da lesão." Até mesmo a doutrina maximalista, como é o caso de Annelise Monteiro STEIGLEDER (2004, p. 237), entende que a "opção fundamental" é a restauração natural do ambiente. Especificamente em relação à opção indenizatória, Luciana Stocco BETIOL (2010, p. 157) ressalta que a indenização pecuniária deve ser tida como última opção "em clara demonstração de que o fim do direito é o de restituir o meio natural ao seu estado primitivo, mesmo porque a indenização não tem o condão de apagar o prejuízo, mas apenas de compensar a vítima". De fato, como lembrado por Patrícia Faga Iglecias LEMOS (2010, p. 209), "a reparação concreta do meio ambiente degradado é sempre preferível ao pagamento de indenização".

A doutrina jurídico-ambiental internacional, assim como a nacional, tem clara opção pela recuperação natural dos danos ecológicos, como demonstram Agathe Van LANG (2011, p. 214) e Eve TRUILHÉMARENGO (2015, p. 247). Van Lang, inclusive, lança a interessante questão da contradição entre o reembolso das despesas relativas às medidas de recuperação ambiental e o estabelecimento de uma indenização pecuniária para a recomposição da degradação. Segundo a autora, ambas são autoexcludentes. Aliás, conforme assinalado por Truilhe-Marengo, a Diretiva 2004/35/CE, claramente, fez a opção pela primazia da recuperação natural em relação à indenização. Apenas à guisa de complemento, vale citar as soluções legislativas de alguns países. No Direito Português, o Código Civil, em seu artigo $566^{\circ}$, I, expressamente determina que a indenização em dinheiro será fixada "sempre que a reconstituição natural não seja possível, não repare integralmente os danos ou seja excessivamente onerosa para o devedor", confirmando, portanto, que a proporcionalidade e a recuperação natural são elementos fundamentais como limites da recuperação natural. O mesmo se diga em relação ao artigo $829^{\circ}$, II relativo às demolições, quando o "prejuízo da demolição para o devedor for consideravelmente superior ao prejuízo sofrido pelo credor". Da mesma forma dispõe o Códi- 
go Civil alemão, no $§ 251$ (1), dispondo que quando a restauração não for possível ou suficiente para compensar o credor, o responsável pelos danos deve fazê-lo pelo restante em dinheiro. Se a recuperação natural somente for possível com despesas desproporcionais, também aí, deverá ser feita a indenização em dinheiro (§. 251(2)). O próprio Código Civil brasileiro permite, por integração análoga, quando se tratar de questões ambientais, identificar que a indenização em pecúnia é etapa posterior à impossibilidade de se cumprir com o objeto da dívida (artigo 947).

\section{FUNDOS AMBIENTAIS}

Em termos de reparação de danos aos interesses difusos - que, como já foi analisado, se assemelham em alguma medida à violação de direitos subjetivos -, o Brasil admite a existência de fundos ambientais com objetivos reparatórios (ANTUNES, 2015, p. 203). Tais fundos são, em nível federal: (i) Fundo de Defesa dos Direitos Difusos ("FDD”), (ii) Fundo Nacional do Meio Ambiente ("FNMA") e (iii) Fundo Amazônia ("FA"). Todavia, nem todos os fundos listados são constituídos por verbas decorrentes de indenizações pecuniárias devidas por danos ecológicos; na verdade, embora os três fundos mencionados tenham entre os seus diferentes objetivos a reparação de danos ecológicos, somente um tem como fonte de recursos as indenizações decorrentes de condenações judiciais pela prática de danos ecológicos.

O FDD tem sua origem na Lei da Ação Civil Pública (Lei Federal $n^{\circ}$ 7.347/1985), que determina que "[h] avendo condenação em dinheiro, a indenização pelo dano causado reverterá a um fundo", cuja destinação será para a "reconstituição dos bens lesados". Percebe-se que há uma contradição na norma, pois a indenização não se confunde com a hipótese de reconstituição dos bens lesados, visto que esta última é uma obrigação de fazer que se consubstancia em um PRAD. Atualmente o FDD é regido pelo Decreto $\mathrm{n}^{\circ} 1.306$, de 9 de novembro de 1994. É importante registrar que os recursos arrecadados pelo FDD deverão ser utilizados em atividades "relacionadas com a natureza da infração ou de dano causado", buscando-se a "reparação específica do dano causado, sempre que tal fato for possível", ou seja, reconheceu-se a impossibilidade da repristinação ao chamado status quo ante.

O FNMA foi criado pela Lei ${ }^{0}$ 7.797, de 10 de julho de 1989, não tendo qualquer relação legal com a reparação de bens naturais, resul- 
tantes de responsabilidade civil. Os recursos do FNMA são destinados à aplicação em (i) unidades de conservação; (ii) pesquisa e desenvolvimento tecnológico; (iii) educação ambiental; (iv) manejo e extensão florestal; (v) Desenvolvimento Institucional; (vi) Controle Ambiental e (vii), desenvolvimento econômico racional e sustentável da flora e fauna nativas.

O FAé um fundo regido pelo Decreto $n^{\circ} 6.527$, de $1^{\circ}$ de agosto de 2008 e administrado pelo Banco Nacional de Desenvolvimento Econômico e Social ("BNDES"), constituído basicamente por doações internacionais, voltado basicamente para a proteção do bioma Amazônia; seus recursos se destinam a: (i) gestão de florestas públicas e áreas protegidas; (ii) controle, monitoramento e fiscalização ambiental; (iii) manejo florestal sustentável; (iv) atividades econômicas desenvolvidas a partir do uso sustentável da vegetação (v) zoneamento ecológico e econômico, ordenamento territorial e regularização fundiária; (vi) conservação e uso sustentável da biodiversidade; e (vii) recuperação de áreas desmatadas. Assim como o FNMA, o FA não tem por característica a de ser um fundo composto por indenizações para recuperação de danos ecológicos.

O FDD teve uma arrecadação total, no ano de 2016, da ordem de $\mathrm{R} \$ 775.042 .663,00^{5}$, dos quais as condenações judiciais relativas a danos ecológicos perfizeram o montante de $\mathrm{R} \$ 2.716 .068,21^{6}$, valor inexpressivo diante do volume de recursos do fundo. Observe-se que, no mesmo período, as infrações cometidas em relação à ordem econômica aportaram R\$ 178.752.647,64 ao FDD. Não se faz uma apreciação sobre os fundos estaduais, pois, na maioria dos estados, a informação não está disponível.

Os parcos recursos recolhidos ao FDD demonstram que o modelo indenizatório por via judicial, como parece ser o preferido no Brasil, é amplamente ineficiente.

\section{RECUPERAÇÃO NATURAL E PROPORCIONALIDADE}

Como já abordado neste artigo, a proteção do meio ambiente, em diversos países, inclusive no Brasil, é uma obrigação constitucional; logo, parece evidente que ela deve ser executada estritamente dentro dos limites constitucionais e legais. Dessa forma, as ações da autoridade pública, com vistas à recuperação de danos ambientais, estão contidas nos limites constitucionais de toda e qualquer ação administrativa.

\footnotetext{
5 Mais informações em: <https://goo.gl/PMC2h5>. Acesso em: 13 abr. 2017. 6 Mais informações em: <https://goo.gl/oviHKa>. Acesso em: 13 abr. 2017.
} 
Como já foi amplamente demonstrado, a recuperação (restauração) natural é a primeira medida a ser adotada para as hipóteses de danos ecológicos. Sabe-se, todavia, que é uma medida de natureza administrativa - na medida em que é submetida ao controle de órgãos ambientais - e, portanto, sujeita aos princípios constitucionais que regem a Administração Pública, no caso brasileiro, contemplados no artigo 37 da CRFB. Ainda que não seja um princípio explícito, a proporcionalidade da ação administrativa é um imperativo de ordem constitucional em um Estado Democrático de Direito.

Em sede legal, a proporcionalidade da ação administrativa está contemplada na Lei de Processo Administrativo Federal (Lei Federal $\mathrm{n}^{\mathrm{o}}$ 9.784/1999), conforme artigo $2^{\circ}$, parágrafo único, inciso VI. No particular, relembre-se Maria da Glória GARCIA (2015, p. 34-35) para quem um "Estado Ambiental" não se confunde com um Estado que suprima a liberdade e o Direito "em nome da defesa do ambiente". Uma das maiores garantias da não supressão das liberdades é dada pelo fato de que o Estado de Direito, mesmo o chamado "Estado de Direito Ambiental" e suas inúmeras variáveis (SARLET e FENSTERSEIFER, 2014, p. 27), age em conformidade com a lei, além de que as suas ações, repressivas ou não, são tomadas proporcionalmente às ações praticadas pelos particulares - mesmo quando expressam atos ilícitos. Em tema de recuperação/reparação de danos ecológicos não é diferente. Com efeito, é a medida proporcional que assegura a colocação de freios à atividade administrativa discricionária, evitando que se transforme em arbitrária, balizando a ação do Estado que é "intérprete-aplicador na concretização da restauração natural" (SENDIN, 1998, p. 218).

A ideia de prevalência das medidas proporcionais para a adoção de procedimentos de recuperação de danos ecológicos é afirmada pela própria PNMA, pois ela é explícita em seu artigo $2^{\circ}$ ao estabelecer a necessidade da compatibilização entre a proteção ambiental e o desenvolvimento econômico. Logo, o próprio PRAD deve ser concebido sem custos ou com custos não excessivos, sob pena de inviabilizar economicamente o responsável pela recuperação natural da área degradada, o que acarretará, como última consequência, a própria paralisação do processo de recuperação natural. Assim, parece evidente que a chamada recuperação integral do ambiente ou a responsabilidade ilimitada por danos ao meio ambiente devem ser tomadas apenas em seu caráter retórico, pois não correspondem (i) às determinações legais e (ii) muito menos a possibilidades concretas, 
em grande parte dos casos, pois a "natureza não se repete".

A propósito, veja-se que o STJ tem, tranquilamente, acolhido a prevalência do princípio da proporcionalidade em matéria de reparação de danos ecológicos, como deixa ver o seguinte trecho de decisão da corte:

\begin{abstract}
No caso em comento, o acórdão recorrido, muito embora reconheça que o Termo de Ajustamento de Conduta, firmado entre as partes, não atende, integralmente, à legislação ambiental, à luz da peculiaridade da demanda, concluiu pela impossibilidade de restauração da vegetação original, tendo em vista tratar-se de trecho totalmente urbanizado. Assim, concluiu pela razoabilidade do acordo firmado no TAC em discussão. V. Nesse contexto, o Tribunal de origem (...) reconheceu (...) que "essa providência, embora insuficiente para restaurar a vegetação original, parece ser a medida mais adequada à singularidade do caso, à luz do princípio da proporcionalidade e do bom senso", concluindo que "o TAC abarca plenamente o requerido nessa AÇÃO CIVIL PÚBLICA. (STJ, AgInt no AREsp 703837 / SP, Relatora Ministra Assusete Magalhães, 2a Turma, DJe 27/09/2016).
\end{abstract}

\title{
CONCLUSÃO
}

A título de conclusão do artigo, é possível constatar que a doutrina, a legislação e a jurisprudência, quando analisadas em conjunto, demonstram que a reparação dos danos ecológicos se faz prioritariamente por meio da restauração natural que, como foi visto, não se confunde com uma abstrata volta a um passado prístino e sem intervenção humana. Ao contrário, a reparação ecológica é definida por um programa de recuperação que indica os limites do que se deve recuperar e como a recuperação deve ser realizada.

É importante registrar que os balizamentos da ação administrativa devem ser observados, inclusive no que diz respeito à proporcionalidade das medidas a serem adotadas, mesmo em termos econômicos. A prática judiciária que, como se sabe, é um importante elemento para informar qual é o direito efetivamente vigente em um determinado país, demonstra que a recuperação de danos ecológicos não se confunde com a imposição de indenizações, salvo nas hipóteses nas quais seja impossível a regeneração natural do ecossistema.

O novo Código de Processo Civil Brasileiro atribui elevado valor ao precedente judicial, o qual pode ser vinculante ou não vinculante, $\mathrm{o}$ 
que implica no reconhecimento do elevado valor para a ordem jurídica da estabilidade da jurisprudência, indicando que decisões consolidadas não podem, pura e simplesmente, ser ignoradas (CÂMARA, 2015, p. 427).

Em assim sendo, o direito vigente não confunde restauração ecológica com repristinação absoluta ao status quo ante da área afetada.

\section{REFERÊNCIAS}

ACKERMAN, Frank e HEINZERLING, Lisa. Priceless - On Knowing the Price of Everything and the Value of Nothing, New York: The New Press, 2004.

ANTUNES, Paulo de Bessa. Dano Ambiental - Uma abordagem conceitual, São Paulo: Atlas, $2^{\mathrm{a}}$ edição, 2015.

ANTUNES, Paulo de Bessa. Direito Ambiental. São Paulo: Atlas, $18^{\text {a }}$ Edição, 2016.

BETIOL, Luciana Stocco. Responsabilidade Civil e Proteção do Meio Ambiente, São Paulo: Saraiva, 2010.

CÂMARA, Alexandre Freitas. O Novo Processo Civil Brasileiro, São Paulo: Atlas, $1^{\text {a }}$ edição, $2^{\mathrm{a}}$ Impressão, 2015.

CARVALHO, Henrique Lopes. A quantificação de Danos Ambientais e a Proteção do Patrimônio Ambiental Brasileiro - Um Exercício de Direito Comparado, Brasília: Revista do TCU, Maio - Agosto 2008, p. 59-70.

CONDESSO, Fernando Reis. Direito do Ambiente. Coimbra: Almedina, 2014.

GARCIA, Maria da Glória F.P.D. O Lugar do Direito na Protecção do Ambiente. Coimbra: Almedina, Reimpressão. 2015.

GOMES, Carla Amado. Introdução ao Direito do Ambiente, Lisboa: AAFDL, 2a edição, 2014.

GOMES, Luiz Flávio e MACIEL, Silvio. Lei de Crimes Ambientais - Comentários à Lei no 9.605/1998, São Paulo: Gen/Método, 2ª edição, 2015. LANG, Agathe van. Droit de L'environnement. Paris: Presses Universi- 


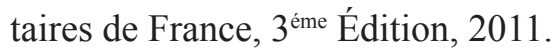

LEITE, Flávia Dinelli Pontes e ALMEIDA, Josimar Ribeiro. Valoração Econômica do Recurso e do Dano Ambiental aplicada à Quantificação de Débito Imputado pelo Tribunal de Contas da União, Brasília: Revista do TCU, Julho - Setembro 2005, p. 77-90.

LEITE, José Rubens Morato e AYALA, Patryck de Araújo. Dano Ambiental - Do individual ao Coletivo Extrapatrimonial, São Paulo: RT, $3^{\text {a }}$ edição, 2010.

LEMOS, Patrícia Faga Iglecias. Direito Ambiental - Responsabilidade Civil e proteção ao meio ambiente. São Paulo: RT, $3^{\text {a }}$ Edição, 2010.

MALINGREY, Philippe. Droit de L'Environnement - comprendre et appliquer la réglementation. Paris: Lavoisier, 6 édition, 2016.

MORAN, Emilio F. People and Nature - An Introduction to Human Ecological Relations, Malden: Blackwell Publishing, 2011.

MOTTA, Ronaldo Seroa da. Valoração Econômica como Critério de Decisão. Brasília: Revista do TCU, Abril-Junho 2004, Edição Comemorativa, p. $92-95$.

OLIVEIRA, Fabiano Melo Gonçalves de. Direito Ambiental, São Paulo: RT, $2^{\mathrm{a}}$ edição, 2010 OST, François. A Natureza à Margem da Lei, Lisboa: Instituto Piaget, 1995.

SARLET, Ingo Wolfgang e FENSTERSEIFER, Tiago. Princípios do Direito Ambiental. São Paulo: Saraiva. 2014.

SENDIM José de Sousa Cunhal. Responsabilidade Civil por Danos Ecológicos - Da Reparação do Dano Através de Restauração Natural. Coimbra: Coimbra Editora, 1998.

SILVA, Danny Monteiro da. Dano Ambiental e sua Reparação. Curitiba: Juruá, 2006.

SILVA, Pedro Paulo de Lima e, GUERRA, Antônio T., MOUSINHO, Patrícia, BUENO, Cecília, ALMEIDA, Flávio G de, MALHEIROS, Telma, SOUZA Jr, Álvaro Bezerra de. Dicionário Brasileiro de Ciências Ambientais, Rio de Janeiro: Thex, 1999. 
STEIGLEDER, Annelise Monteiro. Responsabilidade Civil Ambiental - As dimensões do Dano Ambiental no Direito Brasileiro. Porto Alegre: Livraria do Advogado, 2004.

TRUILHÉ-MARENGO, Eve. Droit de L'Environnement de L'Union Européene, Bruxelles: Larcier, 2015.

Artigo recebido em: 27/04/2017.

Artigo aceito em: 21/08/2017.

\section{Como citar este artigo (ABNT):}

ANTUNES, Paulo de Bessa. A recuperação de danos ecológicos no direito brasileiro. Veredas do Direito, Belo Horizonte, v. 14, n. 29, p. 293-321, mai./ago. 2017. Disponível em: <http://www.domhelder.edu.br/revista/index.php/veredas/article/view/1056>. Acesso em: dia mês. ano. 